\title{
Quantification of Barbatusin and 3 $\beta$-Hydroxy-3-deoxybarbatusin in Plectranthus Species by HPLC-DAD
}

\author{
Maria Goretti de Vasconcelos Silva, Leandro Bezerra Lima, \\ Maria da Conceição Ferreira de Oliveira, Marcos Carlos de Mattos, and Jair Mafezoli \\ Programa de Pós-Graduação em Química, Universidade Federal do Ceará, Campus do Pici, 60455-970 Fortaleza, CE, Brazil \\ Correspondence should be addressed to Jair Mafezoli; jmafez@ufc.br
}

Received 23 April 2017; Accepted 4 June 2017; Published 3 July 2017

Academic Editor: Neil D. Danielson

Copyright (C) 2017 Maria Goretti de Vasconcelos Silva et al. This is an open access article distributed under the Creative Commons Attribution License, which permits unrestricted use, distribution, and reproduction in any medium, provided the original work is properly cited.

\begin{abstract}
The concentration of diterpenes barbatusin (1) and 3 $\beta$-hydroxy-3-deoxybarbatusin (2) in the extracts from leaves of Plectranthus grandis, P. barbatus, P. ornatus, and P. amboinicus was evaluated by HPLC-DAD analysis on a Luna C-18 column, using isocratic mixtures of water and acetonitrile as eluents. The regression equations were obtained with good linearity $\left(r^{2}>0.99\right)$ and limit of quantifications was higher than $0.1 \mu \mathrm{g} / \mathrm{mL}$. The precision (lower than 3.5\%, within day) and accuracy (higher than $81.7 \%$ and lower than $107.6 \%)$ of the methods were adequate. Barbatusin (1) was detected in P. grandis (15.432 $\pm 2.28 \mathrm{mg} / \mathrm{g})$ and $P$. barbatus $(5.198 \pm 3.45 \mathrm{mg} / \mathrm{g})$ extracts, while compound 2 was detected in $P$. grandis $(4.068 \pm 3.34 \mathrm{mg} / \mathrm{g}), P$. barbatus $(0.654 \pm 5.86 \mathrm{mg} / \mathrm{g}), P$. amboinicus $(0.160 \pm 7.25 \mathrm{mg} / \mathrm{g})$, and P. ornatus $(0.763 \pm 5.10 \mathrm{mg} / \mathrm{g})$. The evaluated validation parameters were satisfactorily achieved, and the developed methodology represents a suitable tool for application in the quantification of barbatusin (1) and $3 \beta$-hydroxy3-deoxybarbatusin (2) in Plectranthus species.
\end{abstract}

\section{Introduction}

The Plectranthus genus (Labiatae) is represented by ca. 300 species, which occur essentially in Africa, Asia, Australia, and some Pacific islands. Several species of this genus are cultivated for their edible tubes or as essential oil crops. In addition, some species are used for medicinal purposes such as treating vomiting, nausea, and ear infections; relieving toothache, headache, sores, and burns; or as antiseptic [1]. Species of Plectranthus show biosynthetic ability to produce bioactive diterpenes like the labdane diterpenoid forskolin, from $P$. forskohlii, that shows significant blood pressure lowering properties [2] and the abietane diterpenoids coleon $\mathrm{U}$ and horminone that show antimicrobial activity against methicillin-resistant Staphylococcus aureus and vancomycinresistant Enterococcus faecalis [3]. In Brazil, Plectranthus species are popularly known as "boldo" and widely used as medicinal plants. P. grandis is used in the treatment of gastric and hepatic disturbs, and the gastric hyposecretory activity of this plant was already proven [4]. Several diterpenes present in this plant have shown gastroprotective properties [5-7]. These results validate the popular use of $P$. grandis in the treatment of digestive problems. The abietane diterpenes barbatusin (1) and 3 $\beta$-hydroxy-deoxybarbatusin (2) (Figure 1) were isolated from $P$. grandis and $P$. barbatus $[4,8]$ and showed good gastric protection activity in rats by oral administration $(10 \mathrm{mg} / \mathrm{kg})$. The reduction of the gastric lesions was about $76 \%$ for $\mathbf{1}$ and $96 \%$ for 2 [8].

\section{Experimental}

2.1. General. Acetonitrile and methanol (HPLC grade) were purchased from Tedia ${ }^{\circledR}$. Deionized water was obtained from a Millipore Milli-Q system. All other solvents and reagents were purchased from Synth ${ }^{\circledR}$. Chromatography columns were

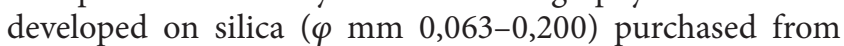




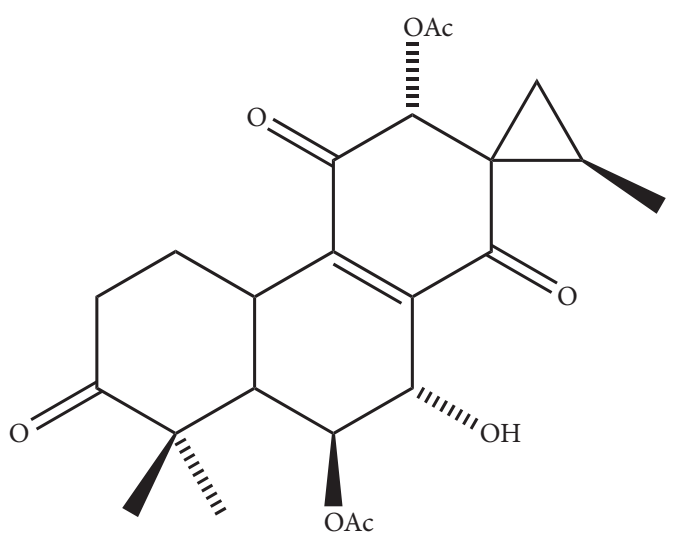

1

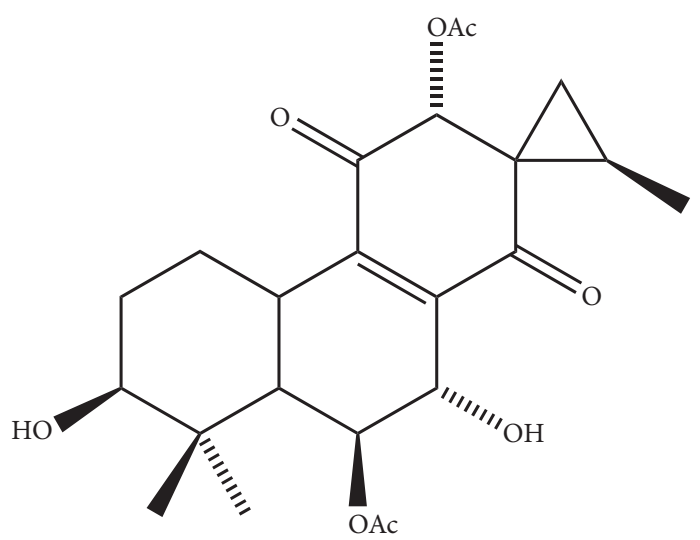

2

FIGURE 1: Chemical structures of barbatusin (1) and 3 $\beta$-hydroxy-3-deoxybarbatusin (2).

Vetec $^{\circledR}$. Analytical TLC was performed on precoated $0.25 \mathrm{~mm}$ thick plates of silica gel 60 F254 from Macherey-Nagel ${ }^{\circledR}$, and the spots were visualized under UV lamp $(254 \mathrm{~nm})$ and by spraying with a solution of perchloric acid-vanillin in $\mathrm{EtOH}$, followed by heating.

2.2. Plant Material. Leaves of P. grandis (\#28377), P. barbatus (\#24408), P. ornatus (\#31929), and P. amboinicus (\#28601), grown under environmental conditions at the Horto de Plantas Medicinais Francisco José de Abreu Matos (official medicinal plant garden from Ceará state, Brazil), were collected in January 2013, and their voucher specimens are deposited in Prisco Bezerra Herbarium-UFC.

2.3. LC System and Chromatographic Method. A Shimadzu UFLC chromatographic system (model LC-20A), with DAD detector (Diode Assay Detector) SPD-M20A, and LC solutions software (version 1.25) were used for data processing. The analyses were conducted on a Phenomenex ${ }^{\circledR}$ Luna $5 \mathrm{u}$ C18 (2) $100 \mathrm{~A}(250 \times 4.60 \mathrm{~mm}, 5 \mu \mathrm{m})$ analytical column in combination with a Phenomenex guard column.

The methodology was based on the analysis of diterpenes in plants by HPLC-DAD [9]. Isocratic elution with $70 \%$ acetonitrile in water was used for compound $\mathbf{l}(\operatorname{method} 1)$ and $45 \%$ acetonitrile in water for compound 2 (method 2$)$. Both methods were carried out at flow rate of $0.8 \mathrm{~mL} / \mathrm{min}$. Temperature of the column was $40^{\circ} \mathrm{C}$, and detection wavelength was $254 \mathrm{~nm}$. Analyses were carried out in triplicate.

\subsection{Sample Preparation and Validation}

2.4.1. Isolation and Identification of Compounds $\mathbf{1}$ and $\mathbf{2}$. The dried leaves $(3.5 \mathrm{Kg})$ of $P$. grandis were extracted with ethanol $(5 \times 8 \mathrm{~L})$ and yielded $295.0 \mathrm{~g}$ of extract after solvent evaporation under reduced pressure. The crude extract was dissolved in $3 \mathrm{~L}$ of water/methanol $(4: 6 \mathrm{v} / \mathrm{v})$ and submitted to liquid-liquid extraction with dichloromethane $(6 \times 100 \mathrm{~mL})$ to yield $60.0 \mathrm{~g}$ of dichloromethane fraction. Successive chromatographic treatments in column, using $\mathrm{SiO}_{2}$ as stationary phase and dichloromethane as mobile phase, gave $3.4 \mathrm{~g}$ of $\mathbf{1}$ and $140.0 \mathrm{mg}$ of 2 . The structures of both diterpenes were confirmed by high-resolution mass spectra, ${ }^{1} \mathrm{H}-\mathrm{NMR}$ $\left(500 \mathrm{MHz}, \mathrm{CDCl}_{3}\right),{ }^{13} \mathrm{C}$-NMR $\left(125 \mathrm{MHz}, \mathrm{CDCl}_{3}\right)$, and comparison with literature data [10].

2.4.2. Preparation of Samples. Leaves from four Plectranthus species (P. grandis, P. barbatus, P. ornatus, and P. amboinicus) were dried at $40^{\circ} \mathrm{C}$, pulverized to powder, and stored in a desiccator. An accurately weighted amount of $1.0 \mathrm{~g}$ of each sample was extracted with $100 \mathrm{~mL}$ of ethanol in ultrasonic bath during 1 hour at $25^{\circ} \mathrm{C}$. Extracts were filtered and the solvent was completely removed by vacuum distillation at $40^{\circ} \mathrm{C}$. Each plant extract was dissolved in methanol (HPLC grade) and transferred to a $25 \mathrm{~mL}$ volumetric flask for a final concentration $0.5 \mathrm{mg} / \mathrm{mL}$ to be analyzed by HPLC-DAD.

2.4.3. Preparation of Standard Solutions. Barbatusin (1) and $3 \beta$-3-hydroxy-3-deoxybarbatusin (2) isolated from leaves of $P$. grandis were used as standards for the analytical curves and method validation. Each diterpene was separately dissolved in methanol (HPLC grade), and the final concentration was adjusted to $1.0 \mathrm{mg} / \mathrm{mL}$. The purities of standard compounds 1 and 2 were determined as $\geq 99 \%$ by HPLC-DAD analyses.

2.4.4. Linearity and Selectivity. Solutions of the standard compounds $\mathbf{1}$ and $\mathbf{2}$ were prepared in methanol at 25, 50, 100, 250 , and $500 \mu \mathrm{g} / \mathrm{mL}$. Then, $20 \mu \mathrm{L}$ aliquots of these solutions were injected into HPLC equipment, in triplicate. For each analyte, the average peak area values were plotted against the respective concentrations, expressed in $\mu \mathrm{g} / \mathrm{mL}$. Both the correlation coefficient $(r)$ and general standard curve equation were obtained from linear least-square regression analysis (Graphpad Prism ${ }^{\circledR} 5.03$ software). The method selectivity was determined through the analyses of the standard compounds 1 and 2 and extracts of the four Plectranthus species. In all extracts, the peaks corresponding to $\mathbf{1}$ and $\mathbf{2}$ were identified by comparison of their retention times with those from the standard compounds. 


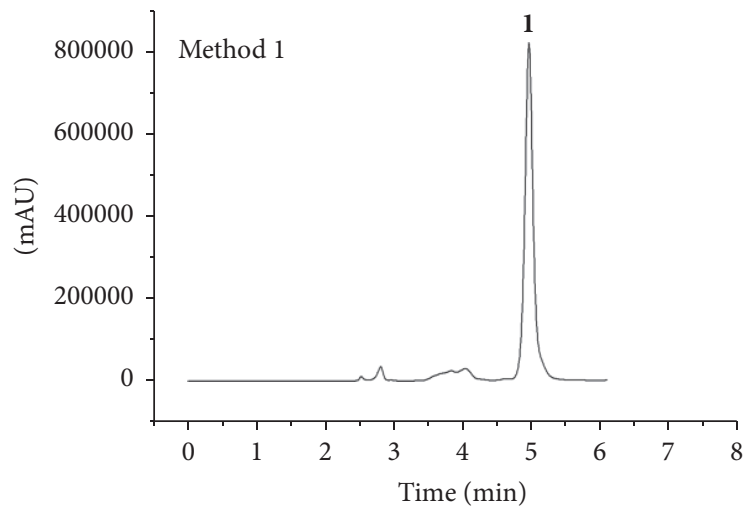

(a)

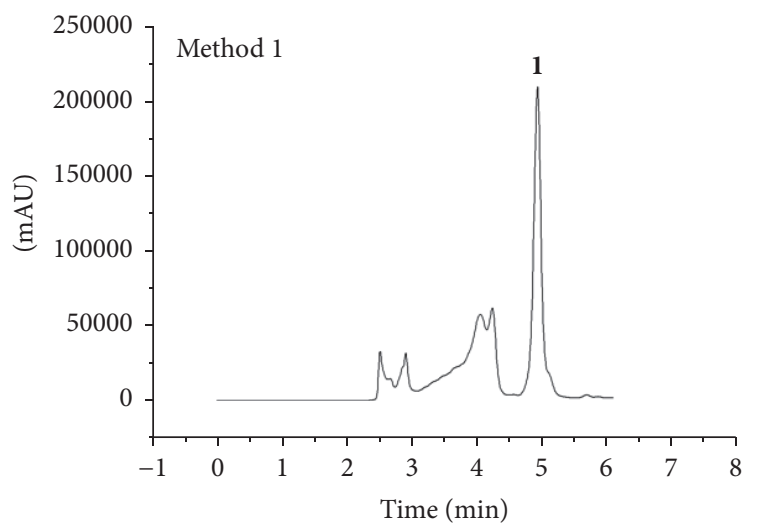

(c)

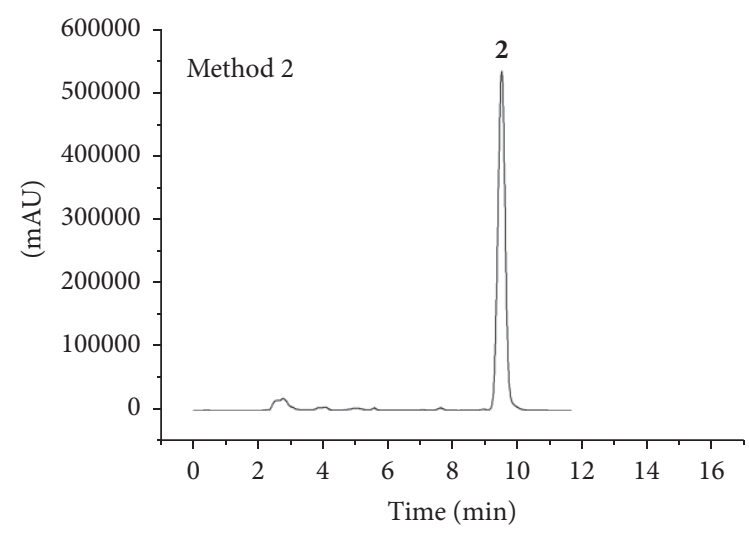

(b)

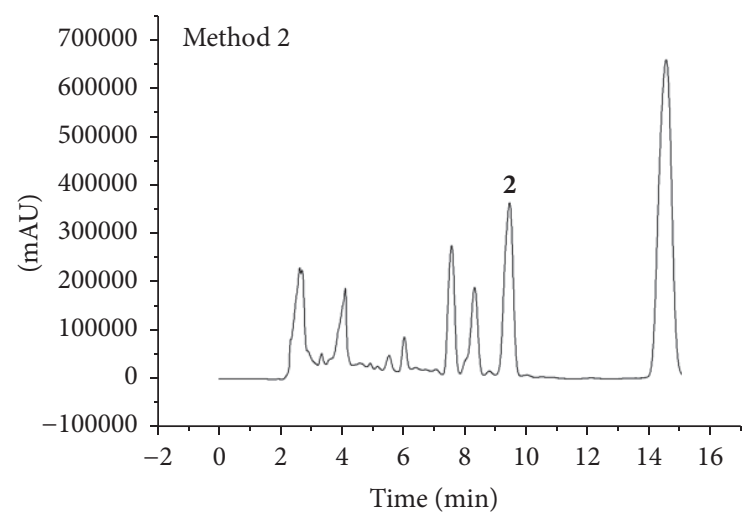

(d)

FIGURE 2: HPLC chromatograms (254 nm) of standard compounds 1 (a) and 2 (b) and the ethanol extract of P. grandis (c and d).

2.4.5. Limits of Detection and Quantification. The limits of detection (LODs, $\mathrm{S} / \mathrm{N} \geq 3$ ) of the two diterpenes 1 and $\mathbf{2}$ were 0.015 and $0.22 \mu \mathrm{g} / \mathrm{mL}$, and the limits of quantification (LOQ, $\mathrm{S} / \mathrm{N} \geq 10$ ) were 0.1 and $0.6 \mu \mathrm{g} / \mathrm{mL}$, respectively.

2.4.6. Precision and Repeatability. The precision of the method was evaluated in two levels, intraday and interdays. Intraday precision was evaluated by nine determinations (triplicate) in three different concentrations. Interdays precision was evaluated using the same three concentrations, during two consecutive days, and by changing operators. The analyses were performed separately for each standard compound. The relative standard deviations (RSD) were calculated for each determination and taken as a measure of precision and repeatability.

2.4.7. Accuracy. The accuracy was determined by recovery tests, which is an estimate of the accuracy of the methods. Extracts containing known amounts of 1 (166.5, 249.0, and $374.0 \mu \mathrm{g} / \mathrm{mL})$ and $2(37.8,47.8$, and $62.8 \mu \mathrm{g} / \mathrm{mL})$, in quintuplicate, were analyzed, besides the extracts with no addition of standard compounds. The recoveries of both standard compounds were calculated from the corresponding calibration curve according to the following equation:

$$
\% \text { recovery }=\left(\frac{\text { amount found }}{\text { amount added }}\right) \times 100 \text {. }
$$

TABLE 1: Analytical parameters of linearity and limits of detection and quantification obtained for $\mathbf{1}$ and $\mathbf{2}$.

\begin{tabular}{lcc}
\hline & \multicolumn{2}{c}{ Analyte } \\
& $\mathbf{1}$ & $\mathbf{2}$ \\
\hline Regression equation & $y=21496 x-20448$ & $y=14145 x+239256$ \\
$r^{2}$ & 0.9931 & 0.9966 \\
LOD $(\mu \mathrm{g} / \mathrm{mL})$ & 0.015 & 0.22 \\
LOQ $(\mu \mathrm{g} / \mathrm{mL})$ & 0.1 & 0.6 \\
\hline
\end{tabular}

\section{Results and Discussion}

Two analytical curves were obtained, one for each standard compound 1 (method 1$)$ and compound $\mathbf{2}(\operatorname{method} 2)$. The linearity of the concentrations versus peak area plot for both methods was determined, and good correlation coefficients were achieved $\left(r^{2}=0.9931\right.$ and $\left.r^{2}=0.9966\right)$. Table 1 shows the linear regression equation and values for the LOD and LOQ which indicates that the developed methods are very sensitive and adequate for the investigated samples. The chromatograms of $\mathbf{1}$ and $\mathbf{2}$ and $P$. grandis extract are shown in Figure 2.

The intraday precision was evaluated by triplicate injection at low, medium, and high concentrations levels. Relative standard deviations were calculated based on observed 
TABle 2: Precision and accuracy for $\mathbf{1}$ and $\mathbf{2}$ in Plectranthus samples.

\begin{tabular}{|c|c|c|c|c|c|c|}
\hline \multicolumn{3}{|c|}{ Precision } & \multicolumn{4}{|c|}{ Accuracy } \\
\hline Analyte & $\begin{array}{l}\text { Amount } \\
\mu \mathrm{g} / \mathrm{mL}\end{array}$ & $\begin{array}{l}\text { Intraday } \\
\text { RSD (\%) }\end{array}$ & $\begin{array}{l}\text { Interday } \\
\text { RSD (\%) }\end{array}$ & $\begin{array}{c}\text { Amount added } \\
(\mu \mathrm{g} / \mathrm{mL})\end{array}$ & $\begin{array}{l}\text { Amount found } \\
\qquad(\mu \mathrm{g} / \mathrm{mL})\end{array}$ & $\begin{array}{c}\text { Recovery } \\
(\text { mean } \pm \text { RSD } \\
\%, n=5)\end{array}$ \\
\hline \multirow{3}{*}{1} & 85.0 & 3.42 & 5.70 & 186.5 & 152.3 & $81.7 \pm 1.74$ \\
\hline & 170.0 & 2.10 & 3.31 & 249.0 & 259.1 & $104.0 \pm 2.10$ \\
\hline & 680.0 & 1.92 & 6.01 & 374.0 & 384.0 & $102.7 \pm 3.39$ \\
\hline \multirow{3}{*}{2} & 65.0 & 3.44 & 2.68 & 37.8 & 40.3 & $107.6 \pm 3.60$ \\
\hline & 130.0 & 3.34 & 6.21 & 47.8 & 50.4 & $105.4 \pm 2.94$ \\
\hline & 325.0 & 1.36 & 10.95 & 62.8 & 64.1 & $102.1 \pm 2.73$ \\
\hline
\end{tabular}

TABLE 3: Concentration of diterpenes $\mathbf{1}$ and $\mathbf{2}$ in leaves of Plectranthus species.

\begin{tabular}{lcc}
\hline Species & $\begin{array}{c}\mathbf{1} \\
\text { (mean } \pm \mathrm{RSD}, \mathrm{mg} / \mathrm{g}, n=3)\end{array}$ & $\begin{array}{c}\mathbf{2} \\
(\mathrm{mean} \pm \mathrm{RSD}, \mathrm{mg} / \mathrm{g}, n=3)\end{array}$ \\
\hline P. grandis & $15.432 \pm 2.28$ & $4.068 \pm 3.34$ \\
P. barbatus & $5.197 \pm 3.45$ & $0.654 \pm 5.86$ \\
P. ornatus & Not detected & $0.763 \pm 5.10$ \\
P. amboinicus & Not detected & $0.160 \pm 7.25$ \\
\hline
\end{tabular}

concentrations. Naturally, interdays precision shows relative standard deviation greater than intraday. The accuracy was performed as recommended, by collecting data from a minimum of nine determinations over a minimum of three concentration levels [11]. Table 2 shows the precision of the methods for $\mathbf{1}$ and 2, which were accurate with recovery rates ranging from 81.7 to $104.0 \%$ for $\mathbf{1}$ and from 102.1 to $107.6 \%$ for 2. The found recovery rates (Table 2) were acceptable since the objective of this study is mainly estimating the amount of diterpenes 1 and 2.

Table 3 shows the concentration $(\mathrm{mg} / \mathrm{g})$ of diterpenes 1 and $\mathbf{2}$ in leaves of the investigated Plectranthus species. Both compounds were detected in $P$. grandis and P. barbatus while $P$. ornatus and $P$. amboinicus showed only the presence of 2 . The highest concentrations of $\mathbf{1}$ and $\mathbf{2}$ were found in the leaves of $P$. grandis. Except in this species, diterpene $\mathbf{2}$ was found in low concentration in the leaves of the studied species. No amount of $\mathbf{1}$ in P. ornatus and P. amboinicus was observed by the employed methodology.

The lack of clear-cut morphological criteria to discriminate some species of Plectranthus has resulted in numerous taxonomic problems for identification of the specimens [1]. Therefore, this work may represent a new tool for discriminating Plectranthus species, by using compounds $\mathbf{1}$ and $\mathbf{2}$ as chemomarkers.

\section{Conclusions}

In summary, the analytical methods were adequate for quantification of diterpenes $\mathbf{1}$ and $\mathbf{2}$ in the leaves of four Plectranthus species. Barbatusin (1) was identified only in the extracts from $P$. grandis and P. barbatus, while compound 2 was present in all Plectranthus species. The highest amount of both compounds $\mathbf{1}$ and $\mathbf{2}$ was found in P. grandis. This is the first report on the identification of $3 \beta$-hydroxy-3deoxybarbatusin (2) in the extracts from $P$. amboinicus and P. ornatus.

\section{Conflicts of Interest}

The authors declare that they have no conflicts of interest.

\section{Acknowledgments}

The authors wish to thank Fundação Cearense de Apoio a Pesquisa (FUNCAP), Conselho Nacional do Desenvolvimento Científico e Tecnológico (CNPq), and Coordenação de Aperfeiçoamento de Pessoal de Nível Superior (CAPES) for financial support.

\section{References}

[1] C. W. Lukhoba, M. S. J. Simmonds, and A. J. Paton, "Plectranthus: a review of ethnobotanical uses," Journal of Ethnopharmacology, vol. 103, no. 1, pp. 1-24, 2006.

[2] H. Hagiwara, F. Takeuchi, T. Hoshi, T. Suzuki, T. Hashimoto, and Y. Asakawa, "First synthesis of 1,9-dideoxyforskolin from ptychantin A," Tetrahedron Letters, vol. 44, no. 11, pp. 2305-2306, 2003.

[3] C. Gaspar-Marques, P. Rijo, M. F. Simões, M. A. Duarte, and B. Rodriguez, "Abietanes from Plectranthus grandidentatus and $P$. hereroensis against methicillin- and vancomycin-resistant bacteria," Phytomedicine, vol. 13, no. 4, pp. 267-271, 2006.

[4] L. A. Fischman, L. A. Skorupa, C. Souccar, and A. J. Lapa, "The water extract of Coleus barbatus Benth decreases gastric secretion in rats," Memorias do Instituto Oswaldo Cruz, vol. 86, p. 141, 1991. 
[5] G. Schmeda-Hirschmann, J. Rodriguez, and L. Astudillo, "Gastroprotective activity of the diterpene solidagenone and its derivatives on experimentally induced gastric lesions in mice," Journal of Ethnopharmacology, vol. 81, no. 1, pp. 111-115, 2002.

[6] P. S. Melo, N. Durán, C. A. Hiruma-Lima, A. R. M. SouzaBrito, and M. Haun, "Comparison of the gastroprotective effect of a diterpene lactone isolated from Croton cajucara with its synthetic derivatives," Journal of Ethnopharmacology, vol. 87, no. 2-3, pp. 169-174, 2003.

[7] J. A. Rodríguez, C. Theoduloz, T. Yáñez, J. Becerra, and G. Schmeda-Hirschmann, "Gastroprotective and ulcer healing effect of ferruginol in mice and rats: Assessment of its mechanism of action using in vitro models," Life Sciences, vol. 78, no. 21, pp. 2503-2509, 2006.

[8] P. D. A. Rodrigues, S. M. de Morais, C. M. de Souza et al., "Gastroprotective effect of barbatusin and 3-beta-hydroxy-3deoxibarbatusin, quinonoid diterpenes isolated from Plectranthus grandis, in ethanol-induced gastric lesions in mice," Journal of Ethnopharmacology, vol. 127, no. 3, pp. 725-730, 2010.

[9] J. Yin, Y. Wang, B. Tan et al., "Matrix solid-phase dispersion extraction for chromatographic analysis of labdane diterpenoids in coleus forskohlii," Phytochemical Analysis, vol. 24, no. 2, pp. 117-123, 2013.

[10] R. L. De Albuquerque, M. R. Kentopff, M. I. L. Machado et al., "Abietane diterpenoids isolation from Plectranthus barbatus," Quimica Nova, vol. 30, p. 1882, 2007.

[11] G. A. Shabir, "Validation of high-performance liquid chromatography methods for pharmaceutical analysis: understanding the differences and similarities between validation requirements of the US Food and Drug Administration, the US Pharmacopeia and the International Conference on Harmonization," Journal of Chromatography A, vol. 987, no. 1-2, pp. 5766, 2003. 

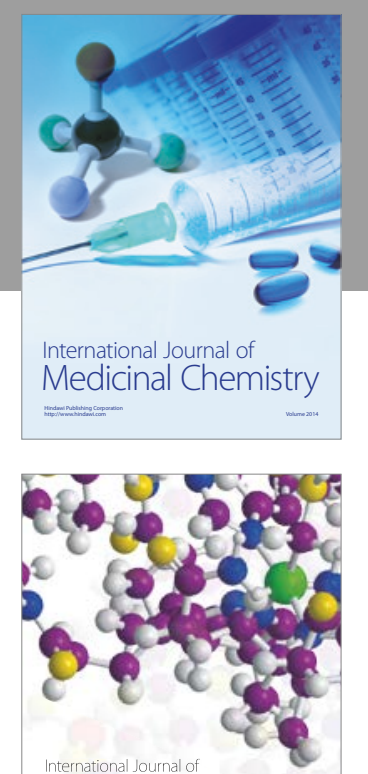

Carbohydrate Chemistry

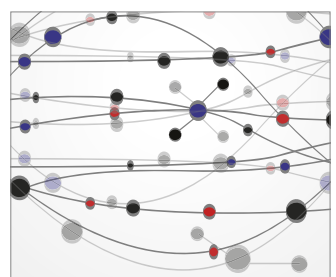

The Scientific World Journal
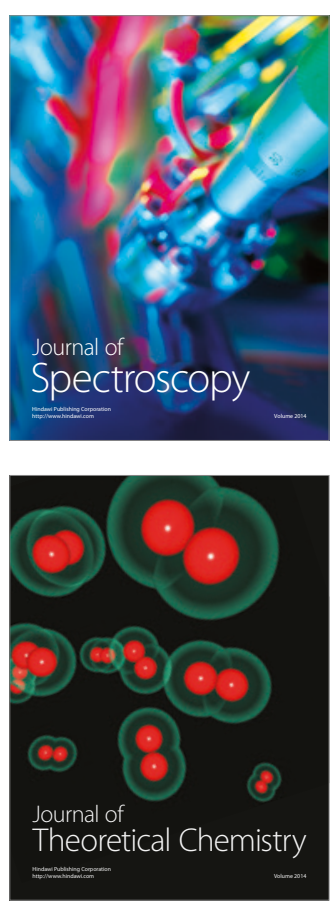
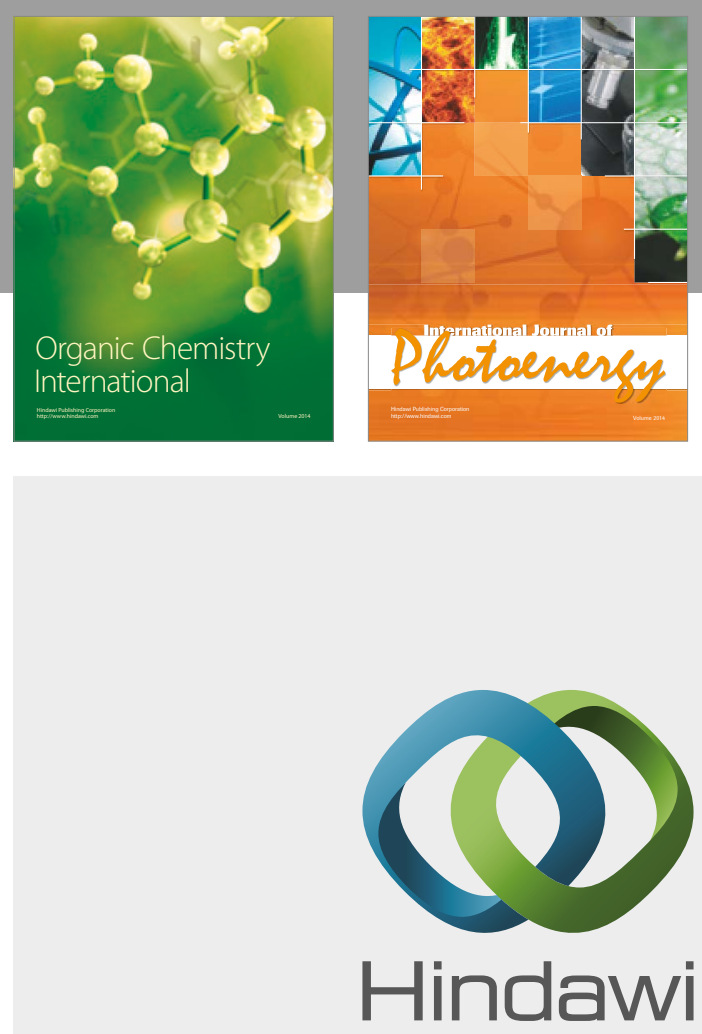

Submit your manuscripts at

https://www.hindawi.com

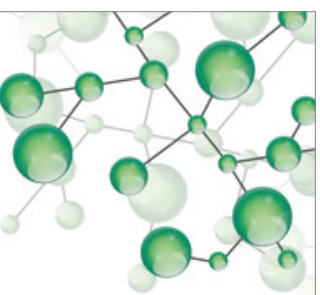

International Journal of

Inorganic Chemistry

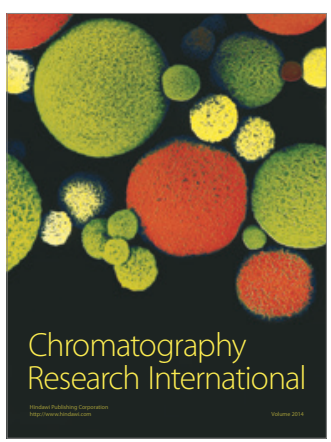

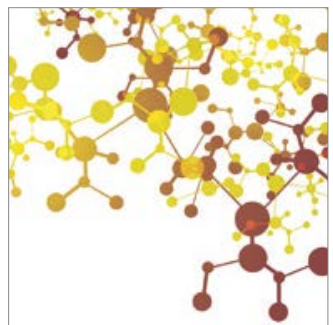

Applied Chemistry
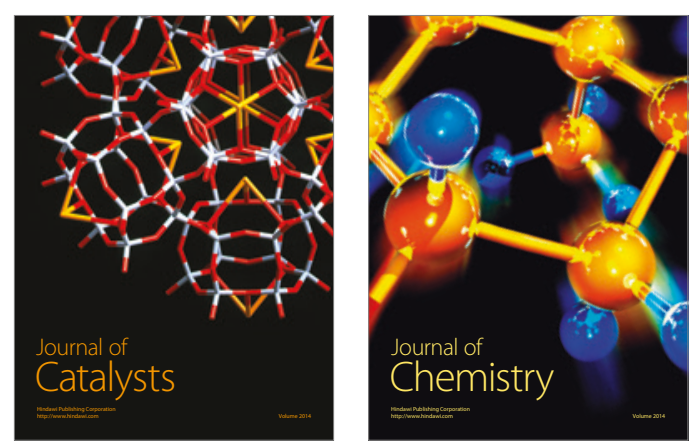
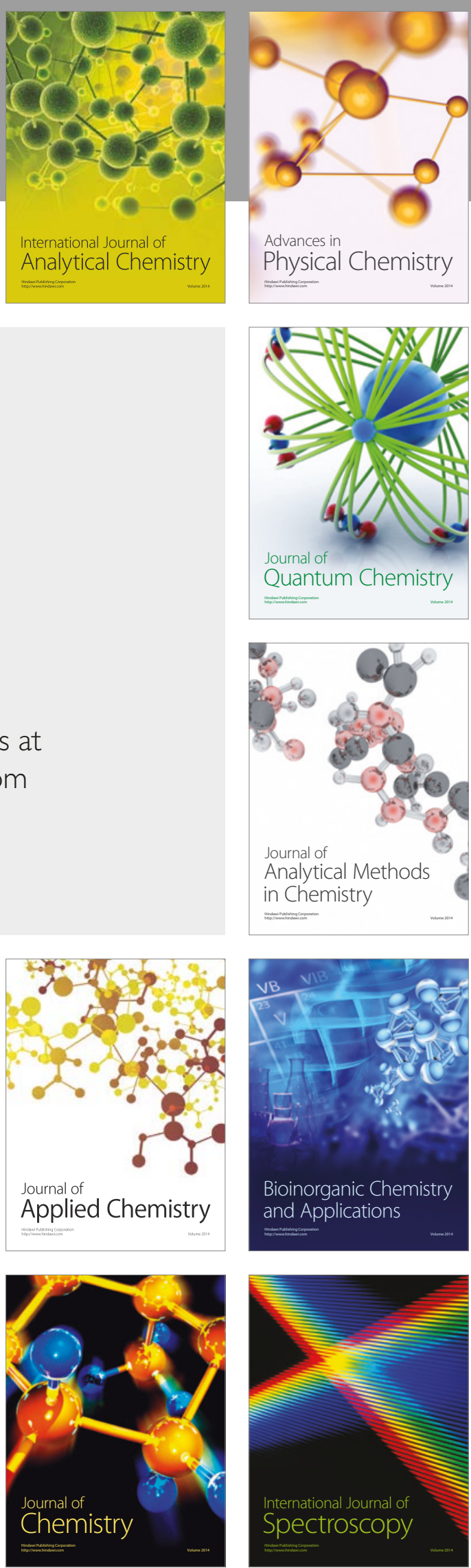